Professor I. M. KoIThOFF, of the University of Utrecht, has accepted a professorship of analytical chemistry at the University of Minnesota and will begin his work in October. Dr. R. S. Livingston, of the University of California, has been appointed assistant professor of physical chemistry.

Dr. Carl Sneed Williamson, formerly of the Mayo Clinic, Rochester, Minn., has been appointed head of the department of surgery at the University of Arkansas School of Medicine, Little Rock, and Dr. Oliver C. Melson, also of the Mayo Clinic, has been appointed head of the department of medicine.

AfTER many years' activity as lecturer on zoology at the institute for investigations in heredity in BerlinDahlem, Dr. Paula Hertwig, the daughter of the former professor of biology, Oskar Hertwig, has been given the title of professor.

\section{DISCUSSION AND CORRESPONDENCE AGE OF THE "SATSOP" AND THE DALLES FORMATIONS OF OREGON AND WASHINGTON}

Geologists have differed regarding the ages of the "Satsop" and the Dalles formations of the Columbia River Gorge region. Because of their bearing on the history of the Gorge and for other reasons their ages are important.

During a brief investigation of these beds under the auspices of the Carnegie Institution of Washington, the writers secured fragmentary mammalian fossil remains from the Dalles formation representing not a Quaternary, but approximately an upper Miocene or lower Pliocene stage. This age determination is corroborated by the lithologic resemblance of the Dalles beds to the middle Neocene Ellensburg formation of central Washington, by the apparently similar relations of these two formations to the Columbia lavas, and by the induration of the Dalles beds, which is equal to that of lower or middle Neocene deposits of the west, but much greater than that of Quaternary formations.

In interesting papers by $\mathrm{J} \mathrm{H}$. Bretz and by I. A. Williams the "Satsop" in the Columbia River Gorge has been considered Quaternary by correlation, mainly through lithologic similarity, with the fossiliferous marine Satsop on the Washington coast. In the eastern part of the gorge, however, the writers have found the "Satsop" gravels beneath the Dalles beds. Moreover, the "Satsop" gravels can be traced into central Washington where they lie at the base of the middle Neocene Ellensburg formation. Further, the induration of the "Satsop" is considerably greater than that of other Pacific Coast upper Pliocene or
Quaternary strata. For these three reasons the "Satsop" of the gorge is also believed to be approximately upper Miocene or lower Pliocene rather than Quaternary.

Since the "Satsop" of the gorge is not the correlative of the type Satsop on the coast, the new name, "Hood River Formation," is proposed for these rather unique conglomerate and sandstone strata. The type section may well be the beds so excellently exposed in the cut immediately east of the Columbia River Highway bridge across Hood River.

A more detailed statement of the evidence and of the bearing of these beds on the geological history of the region is in course of publication.

John P. Buwalda

Bernard N. Moore

California Institute of Technology

\section{MORE DATA}

UNder "Datum and Data" in the July 1 issue of ScIEnce, Mr. Blake says that "We speak and hence write English by ear and not by rules of grammar," and that "in ordinary use," data is not the mere plural of datum. It was, no doubt, recognition of these very unfortunate conditions that prompted the commendable letters of protest regarding the use of "data" in the singular.

There is no standard in the education of ears, and thus it becomes very difficult to eliminate "ain't" from spoken English. The old dictum that use is the law of language presupposes good usage, and the best existing criterion of good usage is a good dictionary. No reputable dictionary admits, or is likely to admit, "data" as a singular form.

But the correspondence which I have seen regarding the misuse of "data" entirely overlooks the chief abuse, which consists, not in using the word incorrectly as a singular, but in using it at all when the intended meaning can be more accurately expressed otherwise. Any one who cares to observe will find that, in probably nine cases out of ten, clearness can be gained by the substitution of "facts," "figures," "records," "values," "results," "information," or any one of perhaps a dozen other words which may more aptly fit the particular case. The general use of "data" for all such cases is due to the same slovenly thinking which causes a writer to use "ete." when he is at a loss for another word; or to use such expressions as "in regard to same" instead of repeating, or specifying just what he means by "same."

The laudable desire to adopt "new" words is to a considerable degree offset by failure to see that they are used accurately, and "data" is only one of a large number used erroneously more often than correctly. Though its use in the singular offends the intelligent 


\section{Science}

AGE OF THE "SATSOP" AND THE DALLES FORMATIONS OF OREGON AND WASHINGTON

John P. Buwalda and Bernard N. Moore

Science 66 (1706), 236.

DOI: $10.1126 /$ science.66.1706.236

ARTICLE TOOLS

http://science.sciencemag.org/content/66/1706/236.1.citation

PERMISSIONS

http://www.sciencemag.org/help/reprints-and-permissions

Use of this article is subject to the Terms of Service

Science (print ISSN 0036-8075; online ISSN 1095-9203) is published by the American Association for the Advancement of Science, 1200 New York Avenue NW, Washington, DC 20005. The title Science is a registered trademark of AAAS.

Copyright (C) 1927 The Authors, some rights reserved; exclusive licensee American Association for the Advancement of Science. No claim to original U.S. Government Works. 